\title{
Identification of SNP g.10428C $>$ T of Stearoyl-CoA Desaturase gene related to meat quality in Bali cattle using PCR-RFLP method
}

\author{
S.N. Karimah ${ }^{1}$, R.R. Noor ${ }^{2}$ and J. Jakaria ${ }^{2, *}$ \\ ${ }^{1}$ Graduate School of Animal Production and Technology, Faculty of Animal Science, \\ $I P B$ University \\ ${ }^{2}$ Department of Animal Production and Technology, Faculty of Animal Science, \\ $I P B$ University \\ Jl. Agatis, Dramaga Campus, Bogor, 16680 - Indonesia \\ *Corresponding E-mail : jakaria@apps.ipb.ac.id
}

Received March 08, 2021; Accepted August 29, 2021

\begin{abstract}
ABSTRAK
Penelitian ini bertujuan untuk menganalisis keragaman Single Nucleotide Polymorphism (SNP) g.10428C $>$ T gen Stearoyl-CoA Desaturase (SCD) menggunakan metode PCR-RFLP dan hubungannya dengan karakteristik daging pada sapi Bali. Total 52 sampel darah sapi Bali dari BPTU-HTP Denpasar kemudian dibandingkan dengan sapi Belgian-blue $(n=30)$, Limousine $(n=14)$, Peranakan Ongole (PO) $(n=30)$ serta Wagyu $(n=7)$ digunakan dalam penelitian ini. Keragaman SNP g. 10428C $>$ T gen SCD dianalisis dengan teknik PCR-RFLP menggunakan enzim pemotong Hinfl. Karakteristik kualitas daging pada sapi Bali diduga menggunakan citra ultrasonografi. Frekuensi genotipe dan alel, nilai heterozigositas, dan kesetimbangan Hardy-Weinberg dihitung menggunakan program PopGen 1.32. Asosiasi genotipe dari SNP g. 10428C $>$ T gen SCD dengan karakteristik kualitas daging dihitung menggunakan uji-t. Hasil penelitian ditemukan genotipe homozigot (CC dan TT) dan genotipe heterozigot (CT) dari gen SCD $\mid$ Hinfl dengan frekuensi alel C $(0,26)$ dan T $(0,74)$ pada sapi Bali. Genotipe CC ditemukan pada sapi Belgian-blue, Limousine, $\mathrm{PO}$, dan Wagyu dengan frekuensi alel $\mathrm{C}$ adalah 1,00. Adapun nilai heterozigositas pengamatan $\left(\mathrm{H}_{\mathrm{o}}=0,44\right)$ dan heterozigositas harapan $\left(\mathrm{H}_{\mathrm{e}}=0,39\right)$ yang memperlihatkan keragaman tinggi pada sapi Bali. SNP g.10428C $>$ T gen SCD berasosiasi dengan sifat ketebalan lemak punggung, skor marbling, dan persentase lemak intramuskular. Dengan demikian SNP tersebut memiliki potensi sebagai kandidat marker-assisted selection pada sapi Bali.
\end{abstract}

Kata Kunci : gen SCD, kualitas daging, PCR-RFLP, sapi Bali, SNP

\section{ABSTRACT}

The objectives of this research was to analyze the polymorphisms of SNP g.10428C $>\mathrm{T}$ in the SCD gene using PCR-RFLP and its association with meat charactheristics in Bali cattle. The number of 52 Bali cattle from BPTU-HTP Denpasar were used in this study and which were compared to Belgianblue $(n=30)$, Limousine $(n=14)$, Peranakan Ongole $(P O)(n=30)$ and Wagyu $(n=7)$. The polymorphism of the SCD gene was characterized by the use of the PCR-RFLP technique with HinfI enzyme restriction. The characteristics of the meat quality in Bali cattle were estimated using ultrasound imaging method. Genotyphic and allelic frequencies, heterozygosity values, and the Hardy-Weinberg equilibrium have been calculated using PopGen 1.32. The association between genotypes of SNP g.10428C $>$ T $\mathrm{SCD}$ gene and meat quality characteristics was calculated using t-test. The results showed that homozygous genotypes (CC and TT) and heterozygous genotypes (CT) of the $\mathrm{SCD} \mid \mathrm{HinfI}$ gene with $\mathrm{C}(0.26)$ and $\mathrm{T}(0.74)$ allele frequencies were and in Bali cattle. The CC genotype was found in Belgian-blue, 
Limousine, PO, and Wagyu cattle with the allele $\mathrm{C}$ frequency of 1.00. The observed heterozygosity $(\mathrm{Ho}=0.44)$ higher than expected heterozygosity $(\mathrm{He}=0.39)$ showed high diversity in Bali cattle. Genotypes of SNP g.10428C $>$ T SCD gene were associated with backfat thickness, marbling score, and percentage of intramuscular fat. Thus the SNPs g.10428C $>$ T have potential as marker-assisted selection candidates for Bali cattle.

Keywords: Bali cattle, meat quality, PCR-RFLP, SCD gene, SNP

\section{INTRODUCTION}

The potential for both native and local beef cattle and even introduced cattle needs to be optimally utilized. The utilization of the potential of beef cattle that are scattered in Indonesia needs to be done, not only to increase meat production but also the quality of meat. Bali cattle as Indonesian native cattle domesticated from banteng (Martojo 2012) have the potential to produce high-quality beef (Hafid et al. 2019). Suryanto et al. (2017) reported that male Bali cattle aged 1.5-2 years had a carcass percentage $54.76 \%$, rib eye area $61.97 \mathrm{~cm} 2$ and backfat thickness $2.80 \mathrm{~mm}$. According to Jakaria et al. (2017) reported that male Bali cattle aged 3 years had, percentage of intramuscular fat $13.48 \pm 3.42 \mathrm{~mm}$ and marbling score $4.50 \pm 1.05$. Meat quality is largely determined by several indicators, such as B vitamins, minerals, iron (Martins et al. 2018) and includes the characteristics of fatty acids (Nogalski et al. 2018).

Meat quality (using marbling score) was controlled by multiple genes such as DGAT1 gene (Li et al. 2013), SREBP gene (Barton et al. 2010), CAPN1 gene (Li et al. 2013) and SCD gene (Ohsaki et al. 2009). Stearoyl-CoA desaturase (SCD) is an enzyme produced in the endoplasmic reticulum, which functions to convert saturated SFA into MUFA, especially from palmitic and stearic to palmitoleic and oleic, which are used for triglyceride synthesis (Mauvoisin and Mounier 2011). The SCD gene in cattle have $17088 \mathrm{bp}$ sequence length and consists of 6 exons and 5 introns on chromosome 26 (Ohsaki et al. 2009). Several studies have reported that there are an association between stearoyl-CoA desaturase (SCD) gene diversity and fatty acid contexture in Wagyu cattle (Taniguchi et al. 2004), Chinese Simmental cattle (Wu et al. 2012), Holstein cross cattle (Kovalchuk et al. 2019), pigs (Estany et al. 2014), sheep (Esteves et al. 2019) and chickens (Furqon et al. 2017).

The relationship between SCD gene diversity and meat quality characteristics is one of the most intensive efforts currently being made to be used as a candidate for genetic traits or referred to as marker-assisted selection (MAS) (Alwiyah et al. 2016). Pereira et al. (2008) reported that one method for determining polymorphism at the molecular level is Polymerase Chain Reaction-Restriction Fragment Length Polymorphism (PCR-RFLP) technique. The PCR-RFLP method is convenient, timeefficient, especially for specific loci, and does not have to identify unknown mutations or to determine base sequences (Hashim and AlShuhaib 2019). Ota et al. (2007) The mutation is discriminated by digestion with specific restriction endonucleases and is identified by gel electrophoresis after staining with ethidium bromide (EtBr). SNP g.10428C $>$ T SCD gene was found to be polymorphic in Bali cattle using direct sequencing analysis and significantly associated with the trait of the marbling score and percentage of intramuscular fat (Alwiyah et al. 2016). According to Taniguchi et al. (2004) the SCD gene is associated with fatty acid composition in meat, IMF deposits (Wu et al. 2012) and meat color (Reardon et al. 2010). It is important to determine the diversity of SCD genes on SNP g.10428C $>$ T in SCD gene using the PCR-RFLP method in Bali cattle and other beef cattle (Belgian-blue cattle, Limousine cattle, PO cattle, and Wagyu cattle). Based on these reasons, this research was conducted to determine the diversity of SNP g.10428C $>$ T of stearoylCoA desaturase (SCD) gene in Bali cattle and other beef cattle (Belgian-blue cattle, Limousine cattle, PO cattle, and Wagyu cattle) using the PCR-RFLP method and its relationship with meat quality characteristics.

\section{MATERIALS AND METHODS}

\section{Animal and Samples}

This study was carried out in the Laboratory of Animal Molecular Genetics, Faculty of Animal Science, IPB University. The samples used consisted of Bali $(n=52)$ from BPTU-HPT Denpasar, Limousine $(n=14)$, and pure breed of 


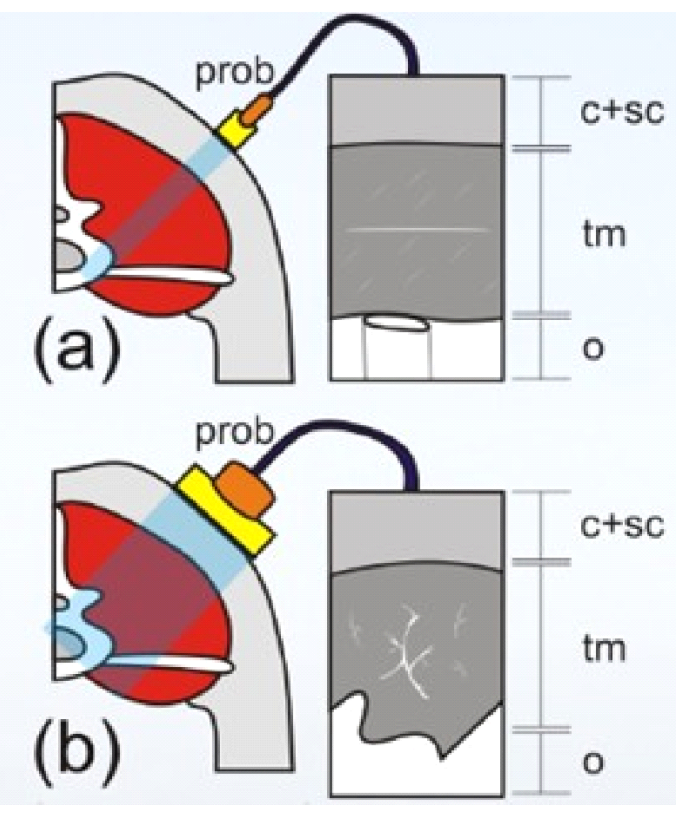

Figure 1. Illustration ultrasound longissimus dorsi in cattle, (a) horizontally (b) vertically, $\mathrm{c}=\mathrm{cutan}$, $\mathrm{sc}=\mathrm{subcu}-$ tan, $\mathrm{tm}=$ thick muscle, $\mathrm{o}=$ bone. Source; Ulum et al. (2014).

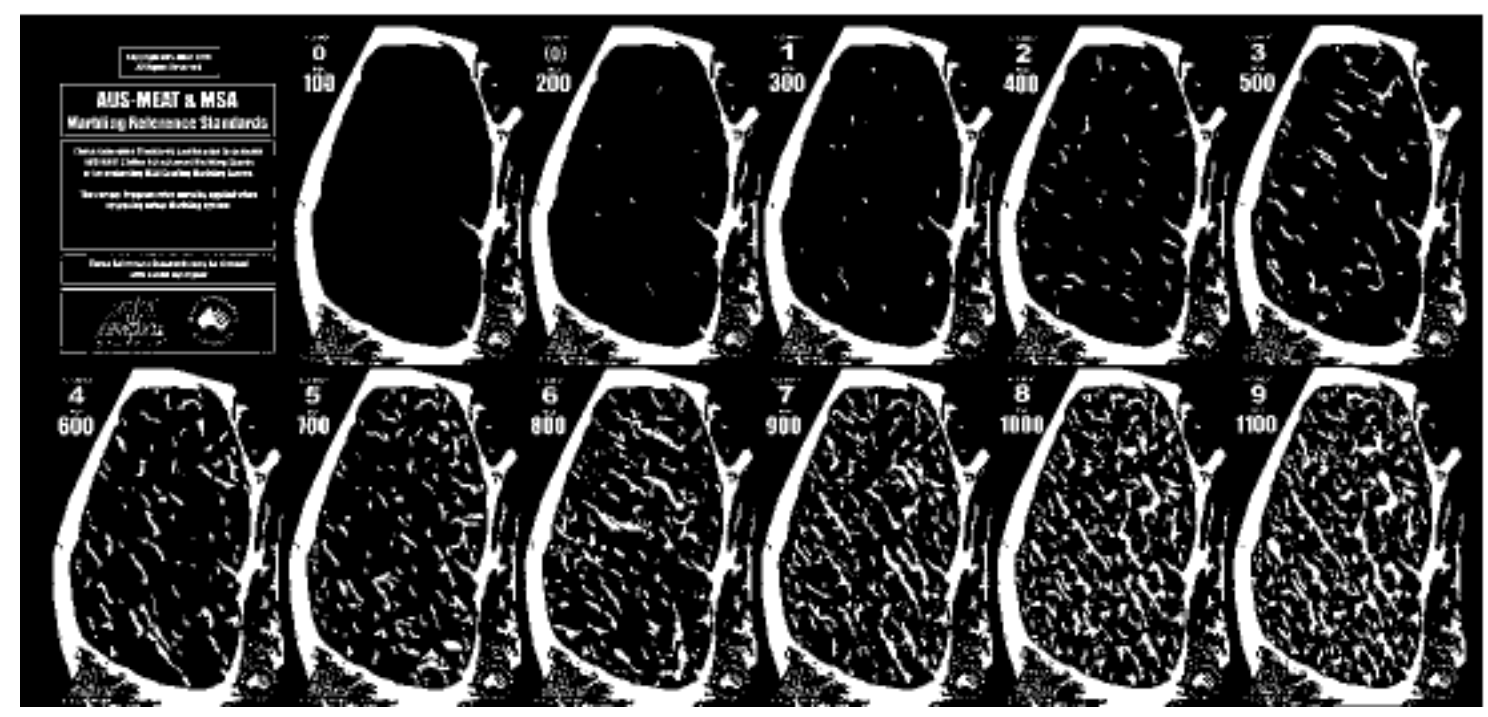

Figure 2. AUS-MEAT and MSA marbling references standards (http://www.wagyu.org.au/marbling/).

Belgian-blue $(\mathrm{n}=30)$ from BPTU-HPT Padang Mangatas, Peranakan Ongol $(\mathrm{n}=30)$ from Kebumen, and pure breed of Wagyu $(n=7)$ from BET Cipelang. The numbers of male Bali cattle used were 52 cattle with an age of 25-35 months.

The meat quality traits analyzed of Bali cattle were carcass and meat characteristics including longissimus dorsi thickness (LDT), backfat thickness (BFT), marbling score (MS) and percentage of intramuscular fat (PIF) as measured by ultrasonography (Figure 1). Ultrasonographic images were taken at frequencies of 4.5 to $6.5 \mathrm{MHz}$ and depths of 8.8 to $13.0 \mathrm{~cm}$. LDT, BFT, MS, and PIF measurements were carried out over ribs 12-13 using Ulum et al. (2014) procedures. The ultrasound results were examined using the Image-J NIH software (Image ${ }^{\circledR}, \mathrm{NIH}, \mathrm{USA}$ ). The Marbling Score val- 
ue was determined by using the MSA and AUSTRALIAN MEAT (http://www.wagyu.org.au/ marbling/) (Figure 2).

\section{Genotyping of SCD Gene using PCR RFLP}

The SNP g.10428C > T of SCD gene is located on the intron 5 used in this research refers to Alwiyah et al. (2016). A pair of primers is forward primer 5'-ACC CCT TGG TGT GTG GTT GTT CTT C-3 ' and reverse primer 5'- CCT GAC GAT ACT ATG TTT CTA CTT C-3' were according to Ohsaki et al. (2009) which partially amplifies exon 5 and intron 5 of SCD gene. The PCR product used consisted of $1 \mu \mathrm{L}$ DNA sample and $14 \mu \mathrm{L}$ of premix solution with $0.3 \mu \mathrm{L}$ of primer, $6.1 \mu \mathrm{L}$ deionized water, and $7.5 \mu \mathrm{L}$ of MyTaq HS Red Mix. The PCR amplification using AB System machine with five process consisted of pre denaturation for 1 minutes at $95{ }^{\circ} \mathrm{C}$ followed by 35 cycles of denaturation for 15 seconds at $95{ }^{\circ} \mathrm{C}$, annealing for 15 seconds at 51 ${ }^{\circ} \mathrm{C}$, and extension for 10 seconds at $72{ }^{\circ} \mathrm{C}$, and a final extension for 1 minutes at $72{ }^{\circ} \mathrm{C}$. The PCR products were detected by $1.5 \%$ agarose gel electrophoresis by staining with PeqGreen for 35 minutes and visualized using an ultraviolet transilluminator.

The PCR product from the polymorphic region (569 bp) of the SCD gene was excreted with Hinfl restriction site. The PCR products and Hinfl restriction enzyme were incubated for 4 hours at $37^{\circ} \mathrm{C}$. The products of DNA fragments from PCR-RFLP were interpreted using agarose gel electrophoresis at an intensity of $2 \%$ by staining with PeqGreen. Electrophoresis was run for 35 minutes at an average voltage of 100 volts. The fragments were visualized under UV Transilluminator. The PCR-RFLP product consisted CC: 569 bp, CT: 569 bp, 318 bp, and 251 bp, and TT: $318 \mathrm{bp}$ and $251 \mathrm{bp}$.

\section{Data analysis}

Genotype and allele frequencies were analyzed that used genotyping data. Genotype frequency $\left(\mathrm{x}_{\mathrm{ii}}\right)$ and allele frequencies $\left(\mathrm{x}_{\mathrm{i}}\right)$ was calculated using the formula of Nei and Kumar (2000):

$\mathrm{x}_{\mathrm{ii}}=\frac{\sum_{\mathrm{i}=1}^{\mathrm{n}} \mathrm{n}_{\mathrm{ii}}}{\mathrm{N}} \quad \mathrm{x}_{\mathrm{i}}=\frac{\left(2 \mathrm{n}_{\mathrm{ii}}+\sum_{\mathrm{i} \neq \mathrm{j}} \mathrm{n}_{\mathrm{ij}}\right)}{2 \mathrm{~N}}$

Where: $\mathrm{X}_{\mathrm{ii}}$ is the frequency of ii genotype (CC, $\mathrm{CT}$, and TT); $\mathrm{X}_{\mathrm{i}}$ is the frequency of i allele (C and $T) ; n_{i i}$ is the number of the sample of $i j$ geno- type; $\mathrm{n}_{\mathrm{ij}}$ is the number of the sample of $\mathrm{ij}$ genotype, and $\mathrm{N}$ is the population size.

Genetic diversity was calculated using the calculation of the observed heterozygosity value $\left(\mathrm{H}_{\mathrm{o}}\right)$ and Heterozygosity of expectations $\left(\mathrm{H}_{\mathrm{e}}\right) \mathrm{Nei}$ and Kumar (2000);

$$
H_{o}=\sum_{i \neq j} \frac{N_{1 i j}}{N} \quad H_{e}=1-\sum_{i=1}^{q} \quad x_{i}^{2}
$$

Where: $\mathrm{H}_{\mathrm{o}}$ is heterozygosity of observations; $\mathrm{N}_{1 \mathrm{ij}}$ is number of heterozygous individuals at locus 1 , $\mathrm{N}$ is total number of samples, $\mathrm{H}_{\mathrm{e}}$ is expected heterozygosity, $x_{i}$ is frequency $\mathrm{I}, \mathrm{q}$ is total number of samples.

Hardy-Weinberg equilibrium (H-W) (Hartl and Clark 1997):

$$
\chi^{2}=\sum \frac{(\mathrm{O}-\mathrm{E})^{2}}{\mathrm{E}}
$$

Where: $\chi^{2}$ is chi-square; $\mathrm{O}$ is total of observations genotype to-I; $\mathrm{E}$ is total of genotype to expectations to-i.

The association between of the SNP g.10428C $>$ T of SCD gene polymorphism and meat quality traits was performed using t-test procedure to compared between genotypes (Minitab $\AA 18$ Software).

$$
t=\frac{\left(\bar{x}_{1}-\bar{x}_{2}\right)}{s \sqrt{\left(\frac{1}{n_{1}}\right)+\left(\frac{1}{n_{2}}\right)}}
$$

where $\mathrm{s}=\sqrt{\frac{\sum_{i=1}^{n}\left(\bar{x}_{i}-\bar{x}_{1}\right)^{2}+\sum_{i=1}^{n}\left(\bar{x}_{i}-\bar{x}_{2}\right)^{2}}{n_{1+} n_{2}-2}}$

Where: $\bar{x}_{1}$ and $\bar{x}_{2}$ is mean of growth traits and meat characteristics of genotypes and $2 ; \mathrm{n}_{1}$ and $\mathrm{n}_{2}$ is the total of individual genotype 1 and $2, s$ is combined variance.

Prior to the association analysis, the meat characteristics data were corrected based on age (34 months) and the maintenance system (extensive maintenance) with the attend method (Salamena and Papilaja 2010):

$$
X_{i} \text { corrected }=\left[\frac{\bar{X}_{\text {standard }}}{\bar{X}_{\text {observations }}}\right] \times X_{\text {observations-i }}
$$

Where: $\mathrm{X}_{\mathrm{i}}$ corrected $=$ corrected data; $\overline{\mathrm{X}}$ standard $=$ standard group mean; $\bar{X}$ observations $=$ average of group observations; $\mathrm{X}$ observations- $\mathrm{i}=$ value of observations-i. 


\section{RESULTS AND DISCUSSION}

\section{Diversity of the SCD gene in Beef Cattle}

The Stearoyl-CoA desaturase (SCD $\mid$ Hinfl) gene fragment targeting SNP g.10428C $>$ T was successfully amplified at $51^{\circ} \mathrm{C}$ annealing temperature for 15 seconds with a PCR product length of $569 \mathrm{bp}$, while the PCR-RFLP genotyping results obtained three types of genotype, i.e. CC, CT and TT genotypes (Figure 4). The results of genotyping from PCR-RFLP analysis of SCD genes in Bali cattle found three genotypes, namely CC genotypes (569 bp), CT genotypes (569 bp, $318 \mathrm{bp}$, and $251 \mathrm{bp}$ ), and TT genotypes (318 bp and $251 \mathrm{bp}$ ). Other beef cattle (Belgian-blue cattle, Limousine cattle, PO cattle and Wagyu cattle) only one genotype was found, namely the CC genotype.
Table 1 shows that Bali cattle have the highest TT genotype frequency compared to CT and $\mathrm{CC}$ with the allele $\mathrm{C}$ and $\mathrm{T}$ frequencies 0.26 and 0.74, respectively. Belgian-blue, Limousine, PO and Wagyu cattle breeds only have one genotype and allele, namely genotype $\mathrm{CC}$ and allele $\mathrm{C}$, so the frequency of genotype and allele is 1.00. Based on these data, it can be concluded that Bali cattle are polymorphic, while other beef cattle (Belgian-blue cattle, Limousine cattle, PO cattle and Wagyu cattle) are monomorphic. The allele and genotype frequency values equal to or less than 0.99 indicate a diversity of alleles in the population (polymorphic) (Nei and Kumar 2000). This is reinforced by the observed heterogeneity values $\left(\mathrm{H}_{\mathrm{o}}\right)$ and expectations $\left(\mathrm{H}_{\mathrm{e}}\right)$, namely 0.44 and 0.39 , respectively (Table 2 ).

The results of the Hardy-Weinberg balance

Table 1. Genotype and Allele Frequencies of SNP g.10428C $>$ T SCD gene

\begin{tabular}{|c|c|c|c|c|c|c|}
\hline \multirow{2}{*}{ Breed } & \multirow{2}{*}{$\mathrm{N}$} & \multicolumn{3}{|c|}{ Genotype Frequency } & \multicolumn{2}{|c|}{ Allele Frequency } \\
\hline & & $\mathrm{CC}$ & $\mathrm{CT}$ & TT & $\mathrm{C}$ & $\mathrm{T}$ \\
\hline Bali & 52 & $0.038(2)$ & $0.442(23)$ & $0.519(27)$ & 0.260 & 0.740 \\
\hline Belgian Blue & 30 & $1.000(30)$ & $0.000(0)$ & $0.000(0)$ & 1.000 & 0.000 \\
\hline Limousine & 14 & $1.000(14)$ & $0.000(0)$ & $0.000(0)$ & 1.000 & 0.000 \\
\hline $\mathrm{PO}$ & 30 & $1.000(30)$ & $0.000(0)$ & $0.000(0)$ & 1.000 & 0.000 \\
\hline Wagyu & 7 & $1.000(7)$ & $0.000(0)$ & $0.000(0)$ & 1.000 & 0.000 \\
\hline
\end{tabular}

The numbers shown in parenthesis are the number of cattle with the genotype specified.

Table 2. Heterozygosity values and the results of the Hardy-Weinberg equilibrium

\begin{tabular}{lcccc}
\hline \multirow{2}{*}{ Breed } & $\mathrm{n}$ & \multicolumn{2}{c}{ Heterozigositas } & \multirow{2}{*}{$\chi^{2}$ test } \\
\cline { 3 - 4 } & & $\mathrm{H}_{\mathrm{o}}$ & $\mathrm{H}_{\mathrm{e}}$ & $1.044^{\mathrm{ns}}$ \\
\hline Bali & 52 & 0.442 & 0.388 & na \\
Belgian Blue & 30 & 1.000 & 0.000 & na \\
Limousine & 14 & 1.000 & 0.000 & na \\
PO & 30 & 1.000 & 0.000 & na \\
Wagyu & 7 & 1.000 & 0.000 & \\
\hline $\mathrm{n}=$ individual number, $\chi^{2}=$ Chi-square $\left(\chi^{2}<3.84\right.$, db 1$)$, degree of freedom $(\mathrm{df})$. ns $=$ not significant $(\mathrm{P}>0.05)$, &
\end{tabular}

Table 3 Association of SCD gene diversity on SNP g.10428 C $>$ T with meat quality

\begin{tabular}{lcccccc}
\hline & \multicolumn{3}{c}{ Genotype gene SCD $(X \pm$ Std Dev $)$} & & P value \\
\cline { 2 - 7 } Characteristics & CC $(\mathrm{n}=2)$ & CT $(\mathrm{n}=23)$ & $\mathrm{TT}(\mathrm{n}=27)$ & CC vs CT & CC vs TT & CT vs TT \\
\hline LDT (mm) & $57.43 \pm 6.30$ & $51.40 \pm 12.30$ & $51.40 \pm 13.60$ & $0.450^{\text {ns }}$ & $0,449^{\text {ns }}$ & $0,990^{\text {ns }}$ \\
BFT (mm) & $1.48 \pm 0.35$ & $1.84 \pm 0.39$ & $2.21 \pm 0.42$ & $0.407^{\text {ns }}$ & $0,222^{\text {ns }}$ & $0,004^{*}$ \\
MS & $0.84 \pm 0.04$ & $1.27 \pm 0.42$ & $1.27 \pm 0.45$ & $0.001^{*}$ & $0,001^{*}$ & $0,997^{\text {ns }}$ \\
PIF (\%) & $0.93 \pm 0.03$ & $2.02 \pm 1.05$ & $1.98 \pm 1.09$ & $0.001^{*}$ & $0,001^{*}$ & $0,890^{\text {ns }}$ \\
\hline
\end{tabular}

$\mathrm{n}=$ individual number, LDT $=$ Longissimus Dorsi Thickness, BFT $=$ Backfat Thickness, MS $=$ Marbling Score,

$\mathrm{PIF}=$ Percentage of intramuscular fat, ${ }^{*}=$ significantly $(\mathrm{P}<0.05), \mathrm{ns}=$ not significant $(\mathrm{P}>0.05)$ 


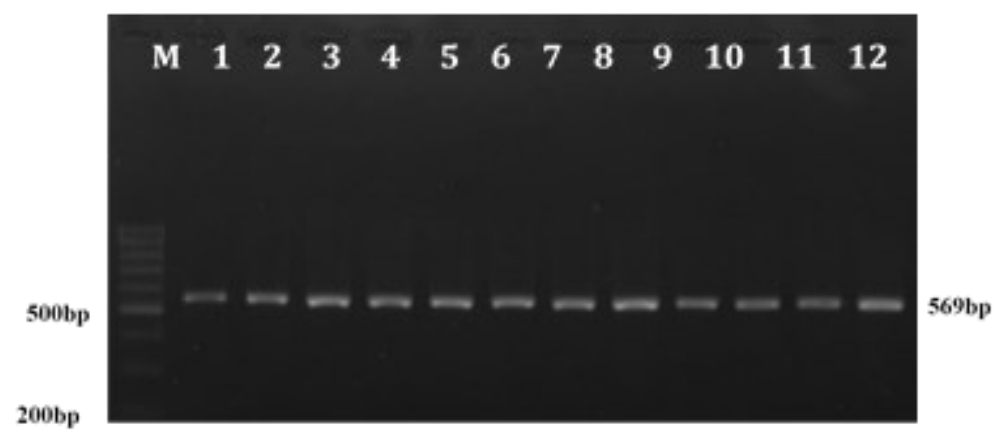

Figure 3. PCR product of SCD gene amplification using $1.5 \%$ agarose $(\mathrm{M}=$ marker $100 \mathrm{bp} ; 1-12=$ individual samples).

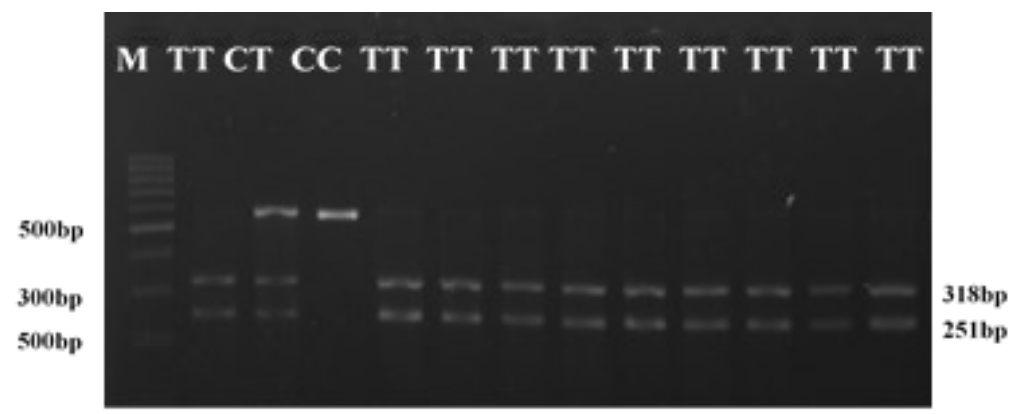

Figure 4. PCR-RFLP technique for genotyping of SCD gene fragments $(\mathrm{M}=$ marker $100 \mathrm{bp}$; CC, CT and TT genotypes).

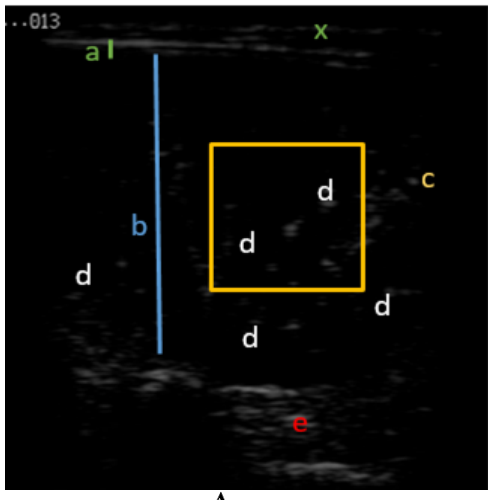

A

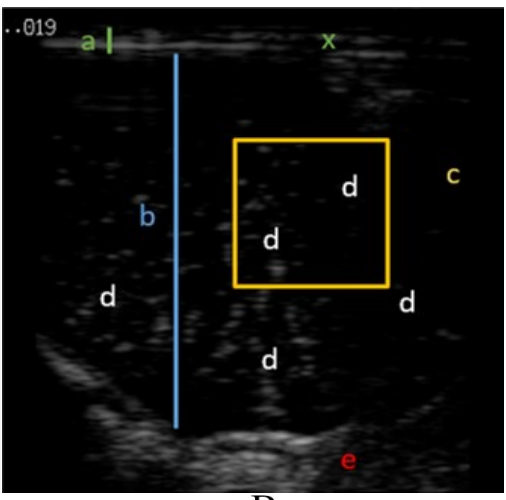

B

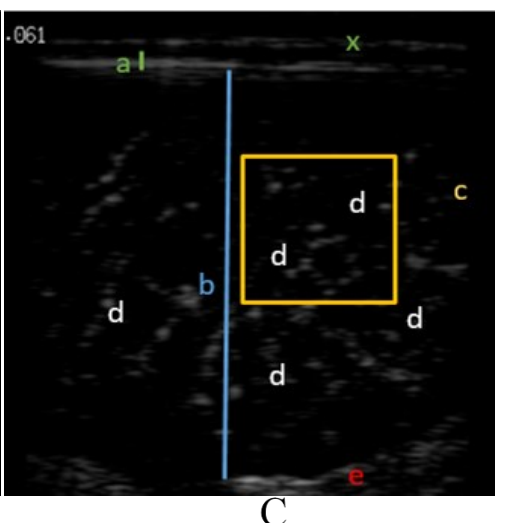

C

Figure 5. Ultrasound image of 12-13th ribs of Bali cattle in a vertical position. (A). genotype CC (B). genotype CT (C). genotype TT. Subcutaneous fat layer (a). Longissimus dorsi thickness (b). percentage measurement area of $15 \times 15$ mm (c) PIF (d). Bone (e). Leather (X).

test on Bali cattle were not significant $(\mathrm{P}>0.05)$, indicating that the genotype frequency of the Stearoyl-CoA desaturase (SCD) gene in the Bali cattle population was in balance. Chesnokov and Artemyeva (2015) clarified, a population with $\mathrm{H}_{\mathrm{o}}$
$>\mathrm{H}_{\mathrm{e}}$ means that in a population there is random mating (random mating), on the other hand, if $\mathrm{H}_{\mathrm{o}}$ $<\mathrm{H}_{\mathrm{e}}$ indicates inbreeding. These results indicate that the Bali cattle population occurs randomly (random mating). Noor (2010) stated, The fac- 
tors that influence the balance of allele and genotype frequencies of a population are non-random mating, selection, migration, mutation, and genetic drift. Allendorf et al. (2010) reported that the population is in a balanced state because the genotype and allele frequencies are stable from generation to generation.

\section{Association of the SCD Gene with Meat char- acteristics of Bali Cattle}

The catalyst descriptions (LDT, BFT MS, and PIF) of meat were only carried out on Bali cattle, while Belgian-blue cattle, Limousine cattle, PO cattle and Wagyu cattle were not analyzed because they were monomorphic. Association of SCD gene diversity on SNP g.10428 C > T with meat quality in Bali cattle are presented in Table 3. Bali cattle with TT genotypes had higher values for backfat thickness traits, compared to the $\mathrm{CC}$ and $\mathrm{CT}$ genotypes (Figure 5). The association results showed that the SCD gene at SNP g.10428 C $>$ T had significant impact with backfat thickness, marbling score, and presentation of intramuscular fat (Table 3). In addition, Alwiyah et al. (2016) where the SCD gene was associated with marbling score and presentation of intramuscular fat in Bali cattle. According to Li et al. (2013), Stearoyl-CoA desaturase (SCD) is one of the genes associated with the fatty acid composition that is solely related to the meat quality. The SCD gene was reported in association with the fatty acid contents of local meat in Ciamis (Hilmia et al. 2016), the fatty acid profile of Japanese Black beef (Taniguchi et al. 2004), and presentation of intramuscular fat of Simental Chinese cattle (Wu et al. 2012).

The quality of beef in cows is built by several factors, namely gender, age, feed, livestock, housing system, pre-slaughter treatment, and genetics (Raza et al. 2019). The genetic influence of carcasses and quality of meat in cattle is relatively large (Ceacero et al. 2016). This can be seen from the heritability value of the quality traits of carcass and meat. Heritability value is the inheritance of a trait from parents in offspring that can be used for selection. The parameter of a value that has a high heritability value can be used as the basis for the individual selection method. This will affect the selection accuracy and the selection response which is expected to be greater than the traits with low heritability (Soeroso et al. 2009). Information on genetic and molecular parameters based on the SCD gene as candidate markers is expected that the accuracy of selection according to the desired trait will be better and have a more significant effect.

\section{CONCLUSION}

The SCD $\mid$ HinfI gene (SNP g.10428C $>$ T) was monomorphic in Belgian-blue, Limousine, PO, and Wagyu cattle, which was polymorphic in Bali cattle. The SCD $\mid$ HinfI gene (SNP g.10428C $>\mathrm{T}$ ) contains three genotypes, such as CC, CT, and TT. The SNP g.10428C $>$ T SCD gene was associated with backfat thickness (BFT), marbling score (MS) and percentage of intramuscular fat (PIF). The SNP g.10428C $>$ T SCD gene has the potential as a candidate marker for the selection of Bali cattle with better meat quality.

\section{ACKNOWLEDGMENTS}

This research was provided funding by the Ministry of Education and Culture for Master Thesis Research Scheme (PTM) with contract Number: 2834/IT3.L1/ PN/2020. The authors thank the head of Bali Cattle Breeding Centre (BPTU-HPT) in Bali Province, BPTU-HPT Padang Mangatas in West Sumatra Province, Village Breeding Centre Kebumen, Animal Embryo Centre (BET) Cipelang, West Java Province, Indonesia for the support and facilities provided during the research.

\section{REFERENCES}

Allendorf, F.W. Hohenlohe, P.A. and Luikart, G. 2010. Genomics and the future of conservation genetics. Nat Rev Genet. 11:697709.

Alwiyah., H Nuraini, P.P. Agung, and Jakaria. 2016. Polymorphism Stearoyl-Coa Desaturase (SCD) gene and associaton with characteristics meat in Bali cattle. J. Indonesian Trop. Anim. Agric. 41:188-195.

Ceacero, T.M Mercadante, M.E.Z. Cyrillo, J.N.S.G, Canesin, R.C. Bonilha, S.F.M. Albuquerque, L.G. 2016. Phenotypic and genetic correlations of feed efficiency traits with growth and carcass traits in nellore cattle selected for postweaning weight. PLoSONE.11:0161366

Chesnokov, Y.V. and Artemyeva, A.M. 2015. Evaluation of the measure of polymorphism information of genetic diversitty. 
Agric Biol. 50:571-578.

Estany, J. Ros-Freixedes, R. Tor, M. and Pena, R.N. 2014. Functional variant in the Stearoyl CoA Desaturase gene promotor enhances fatty acid desaturation in pork. PloS ONE. 9:1-11.

Esteves, C., Livramento, K.G., Paiva, L.V., Peconick, A.P., Garcia, I.F.F., Garbossa, C.A.P., Faria, P.B. 2019. The polymorphisms of genes associated with the profile of fatty acids of sheep. Arq. Bras. Med. Vet. Zootec.71:303-313.

Furqon, A., Gunawan, A., Ulupi, N., Suryati, T., Sumantri, C. Expression and association of SCD gene polymorphisms and fatty acid compositions in chicken cross. Media Peternakan. 40:151-157.

Hafid, H., Hasnudi, Bain, H.A., Nasiu, F., Inderawati, Patriani, P., Ananda, S.H. 2019. Effect of fasting time before slaughtering on body weight loss and carcass percentage of Bali cattle. Proceedings, IOP Conference Series: Earth and Environmental Science. International Conference on Agriculture, Environment, and Food Security 2018. 24-25 October 2018, Medan, Indonesia. P. 1-7.

Hartl, D.L., and A.G., Clark. 1997. Principle of Population Genetic. Sunderland (UK):

Sinauer Associates.

Hashim, H.O., and Al-Shuhaib, M.B.S. 2019. Exploring the potential and limitations of PCR-RFLP and PCR-SSCP for SNP detection: A review. J Appl Biotechnol Reports. 6:137-144.

Hilmia, N., Noor, R.R., Sumantri, C., Priyanto, R., Gurnadi, E. 2016. Analysis of assosiation SCD1 (Stearoyl CoA Desaturase) gene polymorphism with meat fatty acid composition of local cattle at Ciamis. Jurnal Ilmu Ternak. 16:28-34.

Jakaria, H. Khasanah, R. Priyanto, M. Baihaqi, and M.F. Ulum. 2017. Prediction of meat quality in Bali cattle using ultrasound imaging. J. Indonesian Trop. Anim. Agric. 42:59-65.

Kovalchuk, S.N., Anna, L., Arkhipov, Eugene, Klimov, A. 2019. Evelopment of realtime PCR assay for genotyping SNP rs41255693 in cattle SCD gene. AIMS Agriculture and Food. 5:14-19.

Li, X., Ekerljung, M., Lundström, K., Lundén, A. 2013. Association of polymorphisms at DGAT1, leptin, SCD1, CAPN1 and CAST genes with color, marbling and water holding capacity in meat from beef cattle populations in Sweden. Meat Science. 94:153-158.

Martins, T.S., Lemos, M.V.A., Mueller, L.F., Baldi, F., Amorim, T.R., Ferrinho, A.M., Muñoz, J.A., Fuzikawa, H.I.S., Moura, G.V., Gemelli, J.L., Pereira, A.S.C. 2018. Fat Deposition, Fatty Acid Composition, and Its Relationship with Meat Quality and Human Health. Meat Science and Nutrition. 17-37.

Martojo, H. 2012. Indigenous Bali cattle is most suitable for sustainable small farming in Indonesia. Reprod Dom Anim. 47:10-14.

Mauvoisin, D., and C. Mounier. 2011. Hormonal and nutritional regulation of SCD1 gene expression. Biochemie. 93:78-86

Nei, M., Kumar, S. 2000. Moleculear Evolution and Phylogenetics. New York (US): Oxford University Pr.

Nogalski, Z., Pogorzelska-Przybyłek, P., Sobczuk-Szul, M., Nogalska, A., Modzelewska-Kapituła, M., and Purwin, C. 2018. Carcass characteristics and meat quality of bulls and steers slaughtered at two different ages. Ital J Anim Sci. 17: 279-288.

Noor, R.R. 2010. Genetika Ternak. Jakarta (ID): Penebar Swadaya.

Ohsaki, H. Thnaka, A. Hoashi, S. Sasazaki, S. Oyama, K. Taniguchi, M. Mukai, F. and Mannen, H. 2009. Effect of SCD and SREBP genotypes on fatty acid composition in adipose tissue of Japanese Black cattle herds. Anim. Sci. 80:225-232.

Ota, M., Fukushima, H., Kulski, J. K., and Inoko, H. 2007. Single nucleotide polymorphism detection by polymerase chain reaction-restriction fragment length polymorphism. Nature Protocols. 2: 28572864.

Pereira, F., Carneiro, J., Amorim, A., Pereira, F. 2008. Identification of species with DNAbased technology: Current progress and challenges. Recent Patents DNA Gene Seq. 2:187-200.

Raza, S.H.A., Khan, R., Abdelnour, S.A., ElHack, M.E.A., Khafaga, A.F., Taha, A., Ohran, H., Mei, C., Schreurs, N.M., Zan, L. 2019. Advances of molecular markers and their application for body variables and carcass traits in Qinchuan Cattle. Genes (Basel). 10:1-24.

Reardon, W., A.M., Mullen, T. Sweeney, and R. 
M Hamill. 2010. Association of polymorphisms in candidate genes with colour, water-holding capacity, and composition traits in bovine $\mathrm{M}$. longissimus and $\mathrm{M}$. semimembranosus. J Meat Sci. 86:270275.

Reardon, W., Mullen, A. M., Sweeney, T., \& Hamill, R. M. 2010. Association of polymorphisms in candidate genes with colour, water-holding capacity, and composition traits in bovine $\mathrm{M}$. longissimus and $\mathrm{M}$. semimembranosus. J Meat Sci. 86:270275

Salamena, F.J and Papilaja, J. 2010. Characterization and genetic relationships analysis of buffalo population in MOA island of South-East West Maluku regency of Maluku Province. JITAA. 35:75-82

Soeroso, Y., Duma, and Mozin, S. 2009. Study of Heritability Value ands Genetic Correlations of Growth Traits of Crossbred F Bangkok Cocks Mated Indigenous Hens. J. Agroland 16:67-71

Suryanto, E., B. Bulkaini., S. Soeparno., and I.W., Karda. 2017. Carcass quality, mar- bling, meat cholesterol and non-carcass components of bali cattle fed with fermented cacao shell. Bulletin of Animal Science. 41:72-78

Taniguchi, M., Utsugi, T., Oyama, K., Mannen, H., Kobayashi, M., Tanabe, Y., Ogino, A., and Tsuji, S. 2004. Genotype of stearoyl$\mathrm{CoA}$ desaturase is associated with fatty acid composition in Japanese Black cattle. Mamm Genome. 14:142-148.

Ulum, M.F., Suprapto E., and Jakaria. 2014. Ultrasunograpgy image or Longissimus dorci muscle of Bali cattle. Proceeding, KIVNAS PDHI XIII. Konverensi Ilmiah Veteriner Nasional ke-13 Perhimpunan Dokter Hewan Indonesia, Padang, Indonesia, Nov. 23-26, 2014. P. 368-369.

Wu, X.X., Yang, Z. P., Shi, X. K., Li, J. Y., Ji, D. J., Mao, Y. J., Chang, L. L., and Gao, H. J. 2012. Association of SCD1 and DGAT1 SNPs with the intramuscular fat traits in Chinese Simmental cattle and their distribution in eight Chinese cattle breeds. J Molecular Biology Reports. 39:1065- 1071 . 